\title{
Limits on the Implementation of Contrario Actus Principle in the Procurement of Civil Servants
}

\author{
Risang Pujiyanto \\ Polytechnic of ATK Yogyakarta, Indonesia \\ E-email: risang.pujiyanto@gmail.com \\ Sonny Taufan \\ Polytechnic of STMI Jakarta, Indonesia \\ Netti Iriyanti \\ Polytechnic of ATK Yogyakarta, Indonesia
}

How to cite : Pujiyanto, Risang; Sonny Taufan; Netti Iriyanti. (2018). Limits on the Implementation of Contrario Actus Principle in the Procurment of Civil Servents . UNIFIKASI : Jurnal Ilmu Hukum, 5(2), 76-84. DOI : 10.25134/unifikasi.v5i2.1237

Submitted : 04-06-2018 Revised : 30-07-2018 Accepted : 02-08-2018

\begin{abstract}
Procurement of Civil Servants (PNS) which is not in accordance with the legislations and the general principles of good governance have the potential to become State Administration disputes. One of the examples is a civil servant procurement dispute in Dompu District in 2014 where the Judges decided to reject the plaintiff's claim by considering the Contrario Actus Principle. This research was a normative research by using a statute and case approach. The legal materials used in this research were primary and secondary legal materials. Moreover, the data analysis method used was descriptive qualitative. The results showed that in the Civil Servant Procurement Dispute in Dompu District in 2014, the Judges of Mataram Administrative Court judged that the Dompu District Head, in terms of authority and procedure, did not violate the laws and the general principles of good governance. Moreover, in terms of substance, the Judges considered that the Dompu District Head's decision was in accordance with the Contrario Actus Principle. By looking at the decidende ratio and Law Number 30 of 2014 concerning Government Administration, the limits on the implementation of the Contrario Actus principle in the procurement of Civil Servants are; 1) The withdrawn KTUN is a bound KTUN, 2) The withdrawn KTUN has a defective authority, 3) The withdrawn KTUN has a defective procedure, and/or 4) The withdrawn KTUN has a defective substance which is caused by fraud, coercion, bribe, or error.
\end{abstract}

Keywords: procurement of civil servants, general principles of good governance, Contrario Actus principle

\section{Batasan Penerapan Asas Contrario Actus dalam Pengadaan Pegawai Negeri Sipil}

\begin{abstract}
Abstrak : Pengadaan Pegawai Negeri Sipil (PNS) yang tidak sesuai dengan peraturan perundang-undangan dan Asas-Asas Umum Pemerintahan Yang Baik berpotensi menjadi sengketa Tata Usaha Negara. Salah satu contohnya adalah sengketa pengadaan PNS di Kabupaten Dompu Tahun 2014 dimana Majelis Hakim memutuskan menolak gugatan penggugat dengan pertimbangan Asas Contrario Actus. Penelitian ini merupakan penelitian normatif dengan menggunakan pendekatan undangundang dan pendekatan kasus. Bahan hukum yang digunakan adalah bahan hukum dan bahan hukum sekunder. Metode analisis data yang digunakan adalah deskriptif kualitatif. Hasil penelitian menunjukkan bahwa dalam sengketa Tata Usaha Negara pengadaan PNS Kabupaten Dompu Tahun 2014, Majelis Hakim PTUN Mataram menilai secara kewenangan dan prosedur Bupati Dompu selaku tergugat tidak melanggar peraturan-perundang-undangan dan Asas-Asas Umum Pemerintahan Yang Baik. Sementara secara substansi, Majelis Hakim menilai keputusan Bupati Dompu sudah sesuai dengan Asas Contrario Actus. Dengan melihat ratio decidende dan ketentuan Undang-Undang Nomor No. 30 Tahun 2014 Tentang Administrasi Pemerintahan maka batasan penggunaan asas Contrario Actus dalam pengadaan PNS adalah 1) KTUN yang dicabut merupakan KTUN yang bersifat terikat, 2) KTUN yang dicabut terdapat cacat wewenang, 3) KTUN yang dicabut terdapat cacat prosedur, dan/atau 4) KTUN yang dicabut terdapat cacat substansi yang antara lain disebabkan oleh penipuan, paksaan, sogokan, kesesatan atau kekeliruan
\end{abstract}

Kata Kunci: Pengadaan PNS, Asas Asas Umum Pemerintahan yang Baik, dan Asas Contrario Actus.

\section{INTRODUCTION}

Professional State Civil Apparatus is needed to achieve national goals as stated in paragraph 4 of the 1945 Constitution of the Republic of Indonesia (UUD 1945). It is in accordance with Law Number 5 of 2014 concerning State Civil Apparatus. However, in reality, as many as 1 million Civil Servants
(PNS) are suspected of being unprofessional. ${ }^{1}$ Purwanto and Susanto state that one of the factors causing the low professionalism of civil servants in Indonesia was the procurement system of civil servants (PNS) which is identical with Corruption, Collusion, and

https://news.detik.com/berita/3222790/1-juta-pnsdirumahkan-menteri-yuddy-pns-yang-tak-kompeten-dantak-profesional accessted 1 Februari 2018 
Nepotism (KKN) practices $^{2}$. Meanwhile, the State Administration Agency, in Hadiati, et al., states that the number of frauds in the procurement of civil servants lead to the employees' quality which does not correspond to the organization's needs ${ }^{3}$.

By looking at the reality, the procurement of civil servants should be free from Corruption, Collusion and Nepotism, and should be carried out in accordance with the legislations and the general principles of good governance. In addition, in accordance with Article 53 of Law Number 9 of 2004 concerning Amendments to Law Number 5 of 1986 concerning State Administrative Courts, Decisions of State Administration (KTUN) which are contrary to the legislations and the General Principles of Good Governance (AUPB) can be the reasons for legal suit submission. Thus, KTUN related to the procurement of civil servants, such as the decision of applicants who did not pass the administrative selection, the decision of applicants who passed the selection of PNS procurement, the appointment of CPNS and so on, which are not based on legislations and AUPB has the potential to become a State Administration (TUN) dispute. TUN disputes resolved through the TUN Court are a consequence of changes in the relations between the state and citizens in which citizens who were passive become active recipients in the sense that they can submit a legal suit if they receive inadequate service ${ }^{4}$. Besides, giving the opportunity to citizens to sue KTUN is one of the consequences as a State of Law ${ }^{5}$.

There are a number of State Administration disputes in the procurement of civil servants that have been decided by the Court and the Supreme Court and have

${ }^{2}$ Erwan Agus Purwanto dan Ely Sutanto, 2010, "Meninjau Kembali Remunerasi Sebagai Instrumen Untuk Mewujudkan Profesionalisme PNS : Perspektif Teori Motivasi Internal Dan Eksternal", Jurnal Kebijakan dan Manajemen PNS. Tersedia di website http:/www.bkn.go.id accested 1 Februari 2018.

${ }^{3}$ Sri Hadiati et.al, 2010, Grand Design Reformasi PNS Jakarta: Lembaga Administrasi Negara, pp. 85.

4 Abustan, 2017, "Relasi Lembaga Negara Dalam Perspektif Undang Undang Dasar Negara Republik Indonesia 1945", Jurnal Unifikasi. Tersedia di website https://journal.uniku.ac.id/index.php/unifikasi/issue/view/ 97. Accested tanggal 1 Februari 2018.

5 Jimly Asshiddiqie, 2005, Konstitusi dan Konstitusionalisme Indonesia. Jakarta: Konstitusi Press, pp. 185. permanent legal force, including the Mataram Administrative Court Decision Number 7/G/2015/PTUN-MTR. In the procurement of Dompu District Civil Servants for Fiscal Year 2014, one of the participants sued the Dompu District Head. In its consideration, the Mataram Administrative Court Assembly through Mataram Administrative Court Decision Number 7/G/2015/ PTUN-MTR argued that the Decree of the Dompu District Head Number: 800/77/BKD/2015 concerning Amendments to the Appendix to the Decree of the Dompu District Head Number: 800/334/BKD/2014 was an effort to make corrections on errors found in the administrative validation process and corrections were supposed to be carried out as the responsibility of government administrators. The Mataram Administrative Court Assembly argued that it was in accordance with the contrario actus principle stating that the State Administration who issued a Decree is the one who had the obligation to make corrections to his decision if an error was found ${ }^{6}$. Yet, Ridwan HR argues that decision withdrawal can cause juridical problems because the State Administration law recognizes the principle of rechtmatig that is closely related to the principle of legal certainty, however, this principle does not mean eliminating the possibility of change or revocation of the State Administration decision altogether ${ }^{7}$.

From the State Administration dispute regarding the procurement of Civil Servants, it appears that the general principles of good governance (AUPB) especially the contrario actus principle is the basic consideration of the Judges to cancel the KTUN or reject the plaintiff's claim. AUPB, which derives from the Court and Supreme Court decisions, is normatively become AUPB which should be obeyed by all parties, as explained in Article 10 paragraph (2) of Law Number 30 of 2014 concerning State Administration. By referring to the aforementioned provisions, it seems important to discuss the implementation of AUPB, especially the contrario actus principle, in the State Administration dispute related to Civil Servants Procurement. Therefore, based on the background described above, the problem discussed in this research is formulated into the following question: What

\footnotetext{
${ }^{6}$ Putusan PTUN Medan Nomor 35/G/2015/PTUN-MDN

${ }^{7}$ Ridwan HR, 2017, Hukum Administrasi Negara. Jakarta: PT RajaGrafindo Persada, pp. 168-169.
} 
are the limitations of the implementation of contrario actus principle in the State Administration dispute related to Civil Servants Procurement?

\section{METHOD}

This research is a normative research by using a statute and case approach. The statute approach is carried out by examining the legislations that relate to the legal issues under study, while the case approach is carried out by examining the decidende ratio or legal provisions that the court sees as a provision that must be applied to the cases handled. In this research, the legal materials used are primary legal materials in the form of legislation and secondary legal materials in the form of scientific works as well as from internet that support and relate to the research.

\section{RESULTS AND DISCUSSION}

Limits on the Implementation of Contrario Actus Principle in the Procurement of Civil Servants

SF Marbun states that the term General Principles of Good Governance (AUPB) is a translation from Algemene beginselen van behoorlijk bestuur which was introduced by Comissie de Monchy in 1946-1950 in the Netherlands, as a legal protection for the society towards the possible acts of the authorities which may harm the society ${ }^{8}$. Before the issuance of Law Number 30 of 2014 concerning Government Administration, AUPB is included in various legislations with various types of principles. Some of the legislations include Law Number 28 of 1999 concerning the State Organization that is Clean and Free of Corruption, Collusion and Nepotism, Law Number 9 of 2004 concerning Amendments to Law Number 5 of 1986 concerning State Administrative Courts, Law Number 37 of 2008 concerning the Indonesian Ombudsman, Law Number 25 of 2009 concerning Public Services, Law Number 5 of 2014 concerning State Civil Apparatus, and Law Number 23 of 2014 concerning Regional Government ${ }^{9}$.

\footnotetext{
${ }^{8}$ SF Marbun, 2013. Peradilan Tata Usaha Negara. Yogyakarta: Liberty, pp. 145-146.

${ }^{9}$ Cekli Setya Pratiwi, et.al, 2016, "Penjelasan Hukum Asas-Asas Umum Pemerintahan Yang Baik", Tersedia di website http://leip.or.id/wpcontent/uploads/2016/05/Penjelasan-Hukum-Asas-Asas-
}

At first, AUPB was interpreted as an open principle, but through the Government Administration Law, AUPB that had been practiced in the government administration was realized into binding legal norms. According to the Government Administration Law, AUPB is a principle used as a reference for the use of Government Officials Authority in issuing Decisions and/or Actions in the government administration. Article 10 paragraph (1) of the Government Administration Law contains 8 (eight) principles of AUPB, namely the principle of legal certainty, the principle of benefit, the principle of impartiality, the principle of accuracy, the principle of not misusing authority, the principle of openness, the principle of public interest, and the principle of good service. Whereas, Article 10 paragraph (2) of the Government Administration Law shows that other principles beyond the 8 (eight) principles of AUPB can be recognized as AUPB. According to the explanation of Article 10 paragraph (2) of the Government Administration Law, other general principles beyond the 8 (eight) principles of AUPB are general principles of good governance derived from the district court decisions, or the decisions of the highest court that are not canceled or decisions of the Supreme Court.

The Supreme Court with reference to the doctrine that has developed and has been applied in decisions (jurisprudence) states that there are 10 (ten) AUPB, namely Principles of Equality, Principles of Trust, Principle of Legal Certainty, Principles of Accuracy, Principles of Giving Reason/Motivation, Prohibition of Misusing Authority, and Principles that errors committed by State Administration Officials in issuing KTUN result in losses for justice seekers/society. Meanwhile, M. Hadjon argues that the principle of errors committed by State Administration Officials in issuing KTUN result in losses for justice seekers/society may not be charged or become a risk of the related official $^{10}$. Although the Supreme Court has stated that there are 10 (ten) AUPB, other AUPB sourced from decisions that have permanent legal force (inkracht) also becomes

\footnotetext{
Umum-Pemerintahan-yang-Baik-Hukum-AdministrasiNegara.pdf. Accested tanggal 12 Maret 2018

${ }^{10}$ Philipus M. Hadjon, "Peradilan Tata Usaha Negara dalam Konteks Undang-Undang No. 30 Th. 2014 tentang Administrasi Pemerintahan", Jurnal Hukum dan Peradilan.,Vol. 4 No. 1. Maret 2015, pp. 57.
} 
a reference in issuing KTUN, as explained in Article 10 paragraph (2) of the Government Administration Law. AUPB will always develop in accordance with the society's legal awareness and develop through a court decision so that there is no definite AUPB number ${ }^{11}$.

The contrarius actus principle has the meaning that the decision issued by the state administration official can be automatically canceled by the state administration official itself. The contrarius actus principle is explicitly stated in Article 64 of the Government Administration Law. Article 64 paragraph (1) of the Government Administration Law states that revocation of a decision can be made if there is a defective authority, procedure and/or substance in it. In the explanation section of Article 64 paragraph (1) of the Government Administration Law, defects in authority and procedures are not explicitly explained, while a defective substance is explained as:

1. The Decree are not implemented by the recipient until the time limit specified;

2. The facts and legal requirements that become the basis of the Decree have changed;

3. The Decree can endanger and harm public interests; or

4. The Decree is not used in accordance with the objectives stated in the contents of the Decree.

Meanwhile, Hadjon states that KTUN that can be withdrawn are as follows:

1. Those who have an interest do not comply with the restrictions, conditions or provisions of legislation relating to permits, subsidies, or payments.

2. Those who have an interest have provided incorrect or incomplete data when applying for a permit, subsidy or payment, so that if the data is given correctly or completely the decision will be different ${ }^{12}$.

Prins and Adisapoetra state that the withdrawal of the Decree should consider the following principles:

1. A decision, which is made because the person concerned uses deception, can

\footnotetext{
${ }^{11}$ Ridwan, "Memunculkan Karakter Hukum Progresif dari Asas-Asas Umum Pemerintahan Yang Baik Solusi Pencarian dan Penemuan Keadilan Substantif", Jurnal Hukum Pro Justicia.,Vol. 27 No. 1. April 2009, pp. 76.

${ }^{12}$ Philipus M Hadjon, et. al. 2015. Pengantar Hukum Administrasi Indonesia. Yogyakarta: Gadjah Mada University Press, pp. 250 - 251
}

always be abolished $a b$ ovo (there is nothing from the beginning).

2. A decision in which its contents have not been informed to the person concerned, so a decision that has not become an act in the legal context can be abolished ab ovo.

3. A decision, that is useful for the person concerned and is given to them with certain conditions, can be withdrawn at the time when the subject is not fulfilling the conditions specified.

4. A decision that is useful for the person concerned may not be withdrawn after a certain period, if the situation under the beneficial decision can change into an improper situation after the withdrawal.

5. Due to an incorrect decision, an improper situation is happened. This situation should not be erased, if withdrawing the decision leads a greater loss to the person concerned than the loss suffered by the state due to such improper situations.

6. Retract or change a decision should be done based on formality as determined by the provision makers (contrarius actus principle) $)^{13}$.

Nalle argues that the contrarius actus principle is attached to government officials even though the authority is not mentioned in the relevant legislation ${ }^{14}$. Therefore, if there is an error in a KTUN, the government officials can withdraw KTUN based on the contrarius actus principle.

The contrarius actus principle is one of the AUPB used by the Judge Council to decide State Administration disputes concerning the procurement of civil servants in Dompu District in 2014. Rahardjo states that to assess the Judge's decision is to look at the decidende ratio or legal provisions that are seen as a provision that must be applied to the case handled $^{15}$. Thus, to see the implementation of contrarius actus principle, it is necessary to look at the legal provisions used to decide on civil servant procurement disputes in Dompu District in 2014.

\footnotetext{
${ }^{13}$ Prins, W.F. dan R. Kosim Adisapoetra. 1983. Pengantar Ilmu Hukum Administrasi Negara. Jakarta: Pradnya Paramita, pp. 102 - 103

${ }^{14}$ Victor Imanuel W Nalle, "Asas Contarius Actus pada Perpu Ormas: Kritik dalam Perspektif Hukum Administrasi Negara dan Hak Asasi Manusia", Jurnal Ilmu Hukum. Vol. 4 No. 2. Agustus 2017, pp 255.

${ }^{15}$ Satjipto Rahardjo, 2012, Ilmu Hukum. Bandung : PT. Citra Aditya Bakti, pp. 114.
} 
In the procurement of Civil Servants in Dompu District for Fiscal Year 2014, one of the participants sued the Dompu District Head because through the Decree of the Dompu District Head Number: 800/334/BKD/2014 concerning the Determination of the Graduation of Regional Civil Servant Candidate Procurement Selection for the Dompu District Year 2014, the plaintiff had passed. The Dompu District Head then issued the Decree of the Dompu District Head Number: 800/77/BKD/2015 concerning Amendments to the Appendix of the Decree of the Dompu District Head Number: 800/334/BKD/2014 concerning the Determination of the Graduation of Regional Civil Servant Candidate Procurement Selection for the Dompu District Year 2014 (Object of Dispute), so that the name of the plaintiff as a participant who has passed is not listed. By looking at the legal facts in the trial, the Mataram Administrative Court Assembly in his consideration argued that:

1. Authority Aspects

The Judges argued that by referring to Article 1 Number (14) and Article 58 of Law Number 5 of 2014 concerning State Civil Apparatus; Article 3 Government Regulation Number 97 of 2000 concerning Formation of Civil Servants; Article 1 Number (2), Article 2 and Article 8 of Government Regulation Number 98 of 2000 concerning Procurement of Civil Servants, the Dispute Object is issued by the Dompu District Head as an Administration Official in the Dompu District, West Nusa Tenggara Province. Thus, the issuance of the Dispute Object is included in its authority in accordance with the legislations and the general principles of good governance.

2. Procedural Aspects

The Dispute Object is a correction towards an error found after all stages of selection have been completed, namely after the issuance of the Decree of Dompu District Head Number: 800/334/BKD/2014 concerning the Determination of the Graduation of Regional Civil Servant Candidate Procurement Selection for the Dompu District in 2014. The error found on the ranking list of TKD scores compiled based on the first choice position regardless of the applicant's validation status, so the Committee requests clarification from the
Minister of Administrative Reform and Bureaucratic Reform (MenPan and RB).

As a follow-up, MenPan and RB issued corrections which were then used as a basis by the Dompu District Head to issue the Dispute Object. The Judges concluded that from the procedural aspect, the issuing of the Dispute Object is in accordance with the valid legislation, namely Article 58, Article 62, Article 63 paragraph (1) and (2) ASN Law; Article 2, Article 5, Article 6, Article 7, Article 7A, Article 7B, Article 7C, Article 8, Article 9, and Article 10 of Government Regulations on Procurement of Civil Servants.

\section{Substance Aspects}

The Judges argued that the regulations relevant to the substance or content of the Dispute Object are Article 8 of Government Regulation on Civil Servants Procurement. Based on the legal facts in the trial, the Judges found out that the plaintiff was a participant in the 2014 Dompu District CPNS selection on the Position: ICT Teacher and Supervisor of the Implementation of Government Affairs in the Region. In the administrative selection, the plaintiff is declared as ineligible in the ICT Teacher Position because the educational background determined for this position is Bachelor of Information Technology Education, while the Plaintiff has an Informatics Engineering Bachelor's degree (non-education) which is accompanied by a Deed IV of Education. By referring to Law Number 14 of 2005 concerning Teachers and Lecturers, the use of Deed IV is no longer valid so that the Plaintiff is declared ineligible in ICT Teacher Position. Thus, the plaintiff is declared ineligible in the position of ICT Teacher, while in the Second Position, the Supervisor of the Implementation of Government Affairs in the Region, is declared to be Eligible.

The committee immediately clarifies to MenPan and RB that errors on the ranking list of TKD scores that are prepared based on the first choice position regardless of the validation status of the applicant can be immediately corrected because the written requirement for teachers is Bachelor of Education (S1). The Judges argued that the correction made by the Dompu District 
Head to the Decree of Dompu District Head Number: $800 / 334 / B K D / 2014$ on 24 December 2014 concerning the Determination of the Graduation of Regional Civil Servant Candidate Procurement Selection for the Dompu District so that the Dispute Object was issued, was something that was supposed to do, considering the plaintiff's educational background which does not meet the administrative requirements.

The correction made by the Dompu District Head is needed to be done as the responsibility of the State Officer to create an orderly administration based on valid data and in accordance with the regulations. It corresponds to the contrarius actus principle stating that the State Administration/Officer who issues a Decree is the one who has the obligation to make corrections to his decision if an error is found.

The Mataram Administrative Court Assembly with the Decree Number 7/G/2015/PTUN-MTR on the dispute subject decides as follows:

1. Refusing the Plaintiff's claim entirely;

2. To sentence the Plaintiff to pay court fees with amount Rp. 284.000,00 (Two Hundred Eighty Four Thousand Rupiah).

Based on legislations, administrative law theory and court decisions, it can be stated that the limits on the implementation of contrarius actus principle on the State Administration dispute related to Civil Servants Procurement are as follows:

1. The KTUN is a bound decision

A decision that only implements the existing provisions and there is no freedom for the officials concerned, as stated by Ridwan $\mathrm{HR}^{16}$. KTUN related to the procurement of civil servants is a bound decision so that the Personnel Supervisor Officials only implements the provision.

2. The withdrawn KTUN has a defective authority

The authority to make decisions can only be obtained in two ways, namely, 1) attribution, authority attached to a position, and 2) delegation, transferring the existing

\footnotetext{
${ }^{16}$ Ridwan HR, op.cit, pp. 311.
}

authority ${ }^{17}$. In relation to the procurement of civil servants, the authority is only owned by Personnel Supervisor Officials as declared in Government Regulation on Civil Servants Procurement and obtained by delegation. Article 1 Paragraph (2) of Government Regulation on Civil Servants Procurement declares that Personnel Supervisor Officials include Ministers, Attorney General, State Secretary, Cabinet Secretary, Military Secretary, President Secretary, Vice President Secretary, National Police Chief, Secretariat Leader of the Highest State Institution, Governor and District Head/Regent. The scope of authority in the procurement of civil servants is ranging from planning, announcements, application, screening, appointment of prospective civil servants to the appointment of civil servants (Article 2 of Government Regulation on Civil Servants Procurement).

A defective authority includes; 1) Onbevoegdheid ratione materiae, if a KTUN is not based on legislation or if the KTUN is issued by the State Administration agency or official who is not authorized to issue it; 2) Onbevoegdheid ratione loci, the decision made by the State Administration agency or official is related to matters that are beyond its borders; 3) Onbevoegdheid ratione temporis, the State Administration agency or official has not been authorized or no longer authorized to issue $\mathrm{KTUN}^{18}$. The determination of formation, procurement, and appointment of civil servants is part of concurrent government affairs, there is a section of affairs that is under the government authority, there is a section of affairs submitted to the Province, and there is a section of affairs submitted to the District/City Government. Each authority has been divided according to the valid legislation ${ }^{19}$. Personnel Supervisor Official

\footnotetext{
${ }^{17}$ Philipus M Hadjon, et. al. op.cit, pp. 125

${ }^{18} \mathrm{~W}$. Riawan Tjandra, "Perbandingan Sistem Peradilan Tata Usaha Negara dan Conseil d'etat sebagai Institusi Pengawas Tindakan Hukum Tata Usaha Negara”, Jurnal Hukum IUS QUIA IUSTUM. Vol. 20 No. 3. Juli 2013, pp 433.

${ }^{19}$ Hasan Basri, "Kewenangan Kepala Daerah dalam Menentukan Formasi Pengadaan dan Pengangkatan Pegawai Negeri Sipil Daerah dalam Sistem Kepegawaian di Indonesia", Pakuan Law Review. Vol. 3 No. 2. Juli 2017, pp 128.
} 
is the party authorized to carry out Civil Servants procurement process based on the valid legislation. If the Civil Servants procurement authority is owned by other than Personnel Supervisor Officials, then it will raise the onbevoegdheid ratione material.

3. The withdrawn KTUN has a defective procedure

In accordance with Article 58 paragraph (3) of the ASN Law, Procurement of Civil Servants is carried out through the stages of planning, announcement, application, selection, announcement of selection results, trial period, and appointment of civil servants. Thus, according to the ASN Law, the procurement of civil servants should go through stages, including:

a. Announcement of vacancies in each Government Institution should be open to public by stating the number, type and conditions of vacant positions.

b. The selection process which includes administrative selection, basic competencies selection, and field competencies selection should go through an objective assessment based on competences, qualifications, and other requirements required by the position.

c. The participants who pass the selection are appointed as candidates for Civil Servants which are determined by the Decree of the Personnel Supervisor Officials.

d. The candidates for civil servants who have fulfilled the requirements are appointed as civil servants by the Personnel Supervisor Officials in accordance with the legislation.

A Decree including KTUN in the procurement of civil servants should fulfill the formal requirements in the form of writing procedures, decision form, and notification to the person concerned ${ }^{20}$. The procurement of civil servants which does not meet the formal requirements can be withdrawn.

4. The withdrawn KTUN has a defective substance

In the State Administration dispute regarding the procurement of civil servants

\footnotetext{
${ }^{20}$ SF Marbun, op.cit, pp. 45.
}

in Dompu District in 2014, errors are found when MenPan and RB issued a list of TKD scores compiled based on the formation of the first choice position regardless of the applicant's validation status. The Mataram Administrative Court Assembly argued that there is an error, so that the official issued the KTUN was obliged to make corrections to the KTUN. In accordance with Article 64 paragraph (1) of the Government Administration Law, substance defects occur due to the facts and legal requirements which become the basis of the Decree have changed. Accordingly, in the procurement of Candidates for Civil Servants, if wrong facts are found which are caused by fraud, coercion, bribes, or error and the facts become the basis for making the KTUN, the KTUN that has been made can be withdrawn.

\section{CONCLUSION}

Based on the discussion described above, the following conclusions can be drawn. First, AUPB is not limited to the principles contained in Government Administration Law. Conversely, AUPB which is outside the Government Administration Law should also be used as a guideline by the government, including the contrarius actus principle originating from Mataram Administrative Court which has permanent legal force (inkracht). The contrarius actus principle declares that the State Administration Official who issues a Decree is the one who has the obligation to make corrections to his decision if an error is found. Secondly, the limits on the implementation of contrarius actus principle in the procurement of Civil Servants are; 1) The withdrawn KTUN is a bound KTUN, 2) The withdrawn KTUN has a defective authority, 3) The withdrawn KTUN has a defective procedure, and/or 4) The withdrawn KTUN has a defective substance which is caused by fraud, coercion, bribe, or error.

\section{SUGGESTION}

State Administration dispute related to the procurement of civil servants will occur if an error is found which leads to the fact that the society feels disadvantaged. The use of contrarius actus principle cannot necessarily be done to correct errors in the procurement of civil servants. The anticipatory step in the form 
of acting carefully based on the accuracy principle, complete information and documents, and in accordance with the valid legislation is expected to minimize errors arose in the procurement of civil servants. Thus, the State Administration Officials do not need to take corrective action on errors and the community affected by the State Administration decision is not harmed by the withdrawal of the decision.

\section{Books}

\section{REFERENCES}

Asshiddiqie, Jimly. 2005. Konstitusi dan Konstitusionalisme Indonesia. Jakarta: Konstitusi Press.

Hadiati, Sri, et.al. 2010. Grand Design Reformasi PNS. Jakarta: Lembaga Administrasi Negara.

Hadjon, Philipus M, et. al. 2015. Pengantar Hukum Administrasi Indonesia. Yogyakarta: Gadjah Mada University Press.

HR, Ridwan, 2017. Hukum Administrasi Negara. Jakarta: PT RajaGrafindo Persada.

Mahkamah Agung, 2007.Pedoman Teknis Administrasi dan Teknis Peradilan Tata Usaha Negara: Buku II. Jakarta : Mahkamah Agung. Tersedia di website: http://perpustakaan.bldk.mahkamahagun g.go.id/index.php? $\mathrm{p}=$ show_detail\&id=33 $11 \&$ keywords $=$.

Marbun, SF, 2013. Peradilan Tata Usaha Negara. Yogyakarta: Liberty,

Pratiwi, Cekli Setya,et al, 2016. Penjelasan Hukum Asas-Asas Umum Pemerintahan Yang Baik. Jakarta : Lembaga Kajian dan Advokasi Independensi Peradilan. tersedia di website: http://leip.or.id/wpcontent/uploads/2016/05/Penjelasan-

Hukum-Asas-Asas-Umum-

Pemerintahan-yang-Baik-HukumAdministrasi-Negara.pdf

Rahardjo, Satjipto, 2012. Ilmu Hukum. Bandung : PT. Citra Aditya Bakti,

W.F., Prins dan Adisapoetra, R. Kosim. 1983. Pengantar Ilmu Hukum Administrasi Negara. Jakarta: Pradnya Paramita.

\section{Journals}

Abustan. (2017) "Relasi Lembaga Negara Dalam Perspektif Undang Undang Dasar Negara Republik Indonesia 1945". UNIFIKASI : Jurnal Ilmu Hukum. Vol 4
No.2 Juli 2017. Pp. 55-63. DOI : https://doi.org/10.25134/unifikasi.v4i2.6 93

Ali, Syarif. (2012) "Konsep Pembaharuan Seleksi Calon Pegawai Negeri Sipil", Jurnal Transparansi. Vol. 4 No. 1. Maret 2012. Tersedia di website: http://www.stiami.ac.id/jurnal/detail_jurn al/14/59-konsep-pembaharuan-seleksicalon-pegawai-negeri-sipil.html

Basri, Hasan. (2017) "Kewenangan Kepala Daerah dalam Menentukan Formasi Pengadaan dan Pengangkatan Pegawai Negeri Sipil Daerah dalam Sistem Kepegawaian di Indonesia". Pakuan Law Review. Vol. 3 No. 2. Juli 2017. Pp 98129 Tersedia di website https://repository.unpak.ac.id/tukangna/r epo/file/files-20180329054632.pdf

Hadjon, Philipus M. (2015) "Peradilan Tata Usaha Negara dalam Konteks UndangUndang No. 30 Th. 2014 tentang Administrasi Pemerintahan". Jurnal Hukum dan Peradilan. Vol. 4 No. 1. Maret 2015. Pp. 51-64. DOI : 10.25216/jhp.4.1.2015.51-64

Nalle, Victor Imanuel W (2017). "Asas Contarius Actus pada Perpu Ormas: Kritik dalam Perspektif Hukum Administrasi Negara dan Hak Asasi Manusia”. Jurnal Ilmu Hukum. Vol. 4 No. 2. Agustus 2017. Pp. 244-262. DOI : https://doi.org/10.22304/pjih.v4n2.a2.

Purwanto, Erwan Agus dan Sutanto, Ely (2010). "Meninjau Kembali Remunerasi Sebagai Instrumen Untuk Mewujudkan Profesionalisme PNS: Perspektif Teori Motivasi Internal Dan Eksternal". Jurnal Kebijakan dan Manajemen PNS. Vol. 4 No.2. November 2010. Pp. 36-51. Tersedia di website: https://repository.ugm.ac.id/35940/1/Jurn al_Kebijakan_dan_Manajemen_PNS_Vo lume_1_Nomor_2.pdf

Ridwan. (2009). "Memunculkan Karakter Hukum Progresif dari Asas-Asas Umum Pemerintahan Yang Baik Solusi Pencarian dan Penemuan Keadilan Substantif", Jurnal Hukum Pro Justicia,Vol. 27 No. 1. April 2009, Pp. 67-80. Tersedia di website: https://media.neliti.com/media/publicatio ns/13141-ID-memunculkan-karakterhukum-progresif-dari-asas-asas-umumpemerintahan-yang-baik.pdf 
Tjandra, W. Riawan. (2013). "Perbandingan Sistem Peradilan Tata Usaha Negara dan Conseil d'etat sebagai Institusi Pengawas Tindakan Hukum Tata Usaha Negara", Jurnal Hukum IUS QUIA IUSTUM. Vol. 20 No. 3. Juli 2013, pp 423 - 439. DOI : https://doi.org/10.20885/iustum.vol20.iss 3. art5.

\section{Other Sources}

Gandapurnama, Baban, 1 Juni 2016. "1 Juta PNS Dirumahkan, Menteri Yuddy: PNS yang Tak Kompeten dan Tak Profesional" tersedia di website https://news.detik.com/berita/3222790/1juta-pns-dirumahkan-menteri-yuddy-pnsyang-tak-kompeten-dan-tak-profesional accested tanggal 1 Februari 2018 